\title{
When Rhetoric Meets Reality: Attitudinal Change and Coastal Zone Management in Ghana
}

\author{
Elaine T. Lawson ${ }^{1}$ \\ ${ }^{1}$ Institute for Environment and Sanitation Studies (IESS), University of Ghana, Legon, Ghana \\ Correspondence: Elaine T. Lawson, Institute for Environment and Sanitation Studies (IESS), University of Ghana, \\ Legon, Ghana. E-mail: elaine_t@ug.edu.gh
}

Received: July 11, 2014 Accepted: August 8, 2014 Online Published: September 1, 2014

doi:10.5539/enrr.v4n4p37 URL: http://dx.doi.org/10.5539/enrr.v4n4p37

\begin{abstract}
The current poor state of coastal natural resources in Ghana has been attributed to pressures largely from anthropogenic sources, as well as to the negative attitudes of resource users. In order to facilitate attitudinal change educational programmes have focused on the linear model of behaviour, where an awareness of environmental problems is thought to lead to positive environmental behaviour. This paper presents the results of a study of the environmental attitudes of some coastal residents and the socio-economic milieu in which these attitudes are expressed. The results indicated that (1) majority of the respondents lacked access to basic infrastructure, (2) their main environmental concerns were linked to their desire for better living conditions, (3) they have generally positive environmental attitudes and (4) their positive environmental attitudes did not translate to good environmental behaviour because of factors mentioned in (1) and (2). The paper recommends the consideration of environmental and socio-economic concerns of resource users, which influence behavioural intentions during the policy-making processes.
\end{abstract}

Keywords: attitudinal change, coastal zone, environmental attitudes, environmental behaviour, environmental concerns, Ghana, intentions, natural resources

\section{Introduction}

For thousands of years humans have had a close relationship with the sea, with the vast resources of the ocean are contributing to the survival of coastal communities (English, 2003). The high concentration of human populations along coasts makes coastal ecosystems some of the most impacted and altered worldwide (Adger et al., 2005). For example it is estimated that about $40 \%$ of the human population is compressed into $5 \%$ of the inhabited land-space along the margins of ocean, seas and great lakes (Olsen, 2009). In addition, a United Nations Environment Programme (UNEP) report in 2009 confirmed that key habitats supporting coastal ecosystems, such as mangroves, are declining in area (UNEP, 2012).

The current poor state of Ghana's coastal zone is as result of extensive pressures largely from anthropogenic sources, resulting in environmental and socio-economic impacts on the functioning of the coastal ecosystems. Drivers of degradation include population increase, poverty, over-exploitation of fisheries resources, farming, industrial and extractive activities. For example the decrease in mangroves and coastal shrubs could be attributed to economic and agricultural activities in the coastal zone (Coleman et al., 2005) (Tables 1 and 2).

Table 1. Evidence of coastal degradation in some coastal habitats in Ghana

\begin{tabular}{lccl}
\hline Classes & Area (ha) in 1990 & Area (ha) in 2000 & \% change (1990 to 2000) \\
\hline Water & 116,188 & 117,829 & 1.41 \\
Mangrove & 2,605 & 1,905 & -26.87 \\
Settlement & 1,117 & 1,792 & 37.67 \\
Coastal shrubs & 27,884 & 21,181 & -24.04 \\
Agriculture & 15,363 & 20,450 & 24.88 \\
\hline
\end{tabular}

Source: Coleman et al. (2005). 
Table 2. Mangrove area estimates in Ghana

\begin{tabular}{ccccccc}
\hline Year & 1980 & 1990 & 1997 & 2000 & 2005 & 2006 \\
\hline Area $\left(\mathrm{km}^{2}\right)$ & 181 & 168 & 214 & 138 & 124 & 137 \\
\hline
\end{tabular}

Source: UNEP, 2007.

Another pressing consideration for Ghana is the impact of global environmental change on its coasts and coastal resources. Projected increase of flooding in low and coastal areas might further impact marine ecosystems and coastal livelihoods (EPA, 2011). Damage to the coastal zone in the form of flooding, land loss, and forced migration is estimated to reach $€ 4$ million per annum by the 2020 s, rising to $€ 4.75$ million per annum by the 2030 s (World Bank, 2010). The severity of marine and coastal ecosystem degradation also affects the access of coastal communities to goods and services necessary for life.

Community participation has become an important component of the management of coastal natural resources. In most cases those most affected by resource loss and depletion are the poor people because they directly rely on these resources, with limited alternatives available to them (Nkemnyi et al., 2011; Lawson et al., 2012). Yet there are increasing media reports attributing the current state of degradation in Ghana's coastal zone largely to the negative attitudes of coastal resource users. Attitudes are thought to reflect how natural resources are perceived. According to Schultz et al. (2004), environmental attitudes can be defined as a collection of beliefs, affect and behavioural intentions a person holds regarding environmentally related activities and issues. One of the difficulties of researching into environmental attitudes is identifying the relationship between attitudes and actual behaviour. Yet attitudes are thought to be predictors of behaviour. They also help to estimate support for planned and implemented natural resource management strategies (Sesabo, 2006). Attitudes have also been assessed to help determine future management options (Lepp, 2007; Lawson et al., 2010). In order to facilitate an attitudinal change in the coastal zone some implementing agencies have concentrated on designing educational and awareness programmes, thus focusing on a linear model of behaviour. In this model awareness of environmental problems and knowledge of how to tackle them is thought to lead to positive environmental behaviour. Such a behaviour change is to also lead increased engagement on the part of local communities (Nelson \& Agrawal, 2008; Lawson \& Bentil, 2014). The traditional thinking especially in the field of environmental education has been that knowledge about the environment and its associated issues lead to an increase in awareness and an environmentally responsible behaviour. Attitudes of local resource users can also help shape different forms of environmental management and policies positively (d'Aquino \& Bah, 2013). Although still widely used, most current research on environmental behaviour have criticised this linear model as being simplistic. For example Hines et al. (1987) in discussing his model of responsible environmental behaviour linked a person's desire to act to a host of personality factors, determined by locus of control, attitudes (toward the environment and toward taking action), and personal responsibility (toward the environment). Situation factors, such as economic constraints, social pressures and opportunities to choose different actions could either counteract or to strengthen the variables in the model. The Theory of Reasoned Action (Fishbein \& Ajzen, 1975) and the Theory of Planned Behaviour (Ajzen \& Driver, 1992) both introduced the crucial intention-behaviour relationship (Barr et al., 2007). Hence many of the factors that predict behaviour do so indirectly by first influencing intentions. Other researchers such Kaiser et al. (2005) and Levine and Strube (2012) have made similar findings.

Using 304 women from two coastal communities this paper examines the linkages between environmental attitudes and behaviour in two coastal communities in Ghana. It answers the questions:

1) What is the socio-economic milieu in which environmental decisions are made?

2) What are the main environmental concerns?

3) What are the current trend of environmental attitudes and behaviour in the coastal zone of Ghana?

4) What key elements are required in the translation of attitudes into behaviour?

The significance of this study lies in the fact that it attempts to bridge the gap between research and policy recommending the completion of policy aimed at managing coastal natural resources in Ghana effectively. From the review of studies on coastal resource management in Ghana, it was noted that assessment of community attitudes was not adequately addressed, yet it is one of the key components in effective coastal zone management. Current research has also shown that the factors that may influence attitudes and behaviour towards natural resources are many. They include demographic and socio-economic factors (Pomeroy \& Carlos, 1996; Wright \& Shindler, 2001) such as gender (Hill, 1998; Mehta \& Heinen 2001), age, educational and income levels 
(Fiallo \& Jacobson, 1995). Many studies have shown that people often hold positive attitudes towards their environment (Ramos et al., 2007; Mehta \& Heinen, 2001; Mehta \& Kellert, 1998). Another important consideration is how local people's support for natural resource management can be influenced by benefits (and costs) obtained from these resources as against socio-economic and demographic consideration (Sesabo, 2006; Dolisca et al., 2006). The results of this study also reveal the importance of context in research as well as the difficulty in developing a "one-size-fits-all" solution to changing local resource users' attitudes towards natural resources. Attempts to impose solutions that have worked in developed countries into a developing setting such as prevails in Ghana is a recipe for disaster. Hence the importance of local case studies as is reported in this paper.

\section{Methodological Approach}

The research reported in this paper was undertaken in two communities in the coastal zone of Ghana. A purposive non-probability sampling technique was used to select the communities and the respondents. This method was used because the aim of the study was to reach a specialised population, namely women living in coastal communities. Because the case study approach was used, the generalisations of findings are theoretical rather than statistical. Eisenhardt (1989) further explains that in case studies random selection is neither necessary nor even preferable.

\subsection{Study Areas}

Ghana, a tropical country on the west coast of Africa, is divided into ten administrative regions. The country has an estimated population of about 23.4 million (GSS, 2009) with a population density varying from 897 per km in Greater Accra Region to 31 per $\mathrm{km}^{2}$ in the Northern Region. Ghana's population is predominately rural and the urban population is skewed towards the south with Accra the capital city having $17 \%$ of the total population (ADB, 2011), while adult literacy rate (age 15 and above) stands at 65\%. In addition, Ghana's life expectancy at birth increased by 11.5 years to 64.6 (UNDP, 2013). The country is divided into five distinct geographical regions.

The Ghanaian coastline is $550 \mathrm{~km}$ from the border with Cote d'Ivoire to the border with Togo, and generally covers a low lying area of 30metres above sea level. The offshore zone in Ghana is about $26,000 \mathrm{~km}^{2}$ The continental shelf (200 meters deep) is narrow and generally extends seaward between 20 to 35 kilometres, except in Takoradi where it reaches 90 kilometres. The coastal zone covers areas in the Western, Central, Greater Accra and Volta regions (Figure 1).

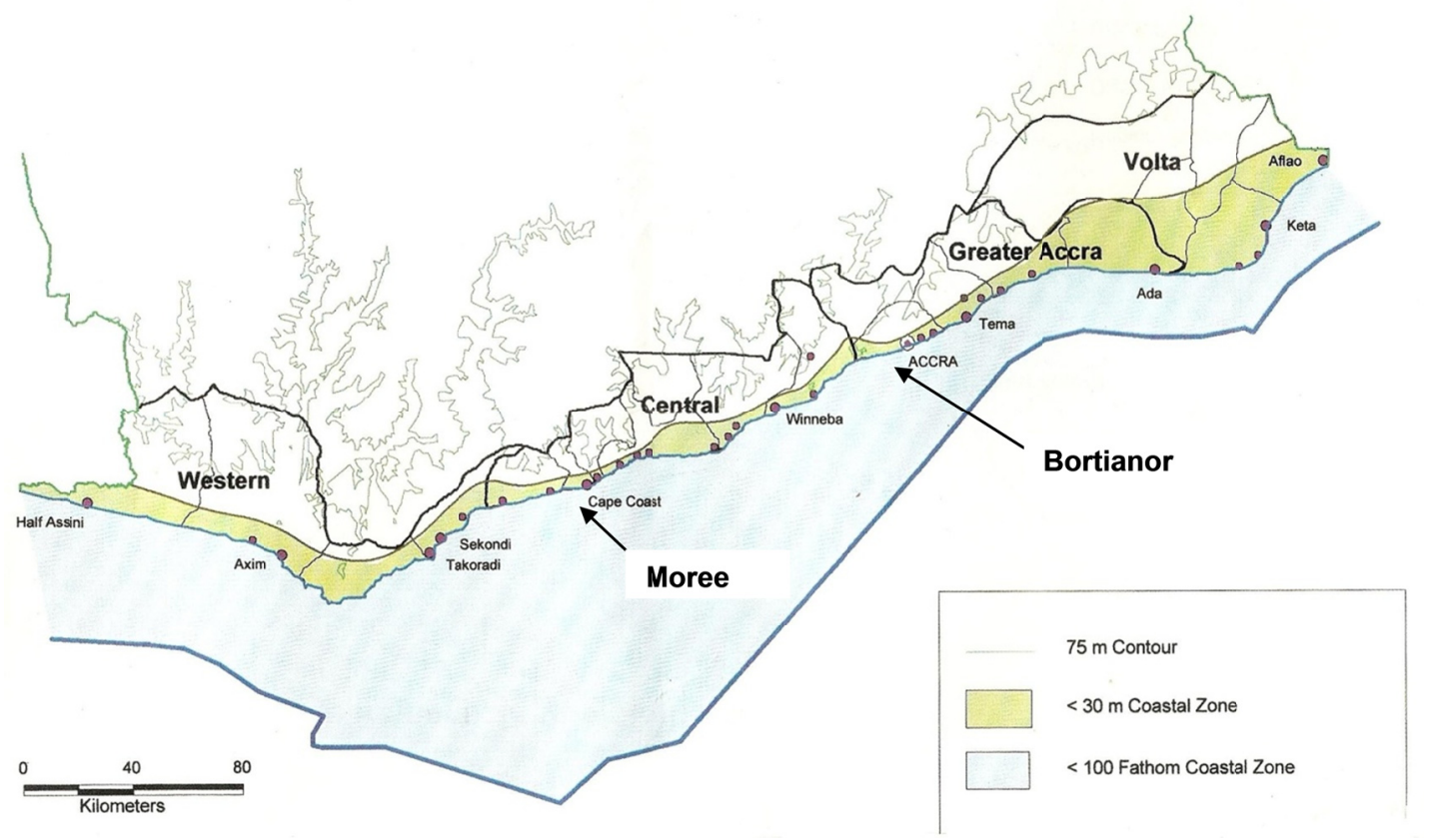

Figure 1. Map of the coastal zone of Ghana

The study communities were chosen because of the high interaction between residents and the coastal natural resources. The first community, Bortianor is found in the Ga South Municipal in Greater Accra Region of Ghana. 
It is a fishing community with a total population estimated in the 2000 Census to be 5,446 . Out of this 2,683 are males whilst 2,763 are females. The main economic activities in the Ga South Municipal include fishing in the coastal areas and farming in the inland areas. The structure of the local economy is predominantly agriculture, followed by the industrial and the service sectors.

The second community, Moree is also a traditional fishing community found on a rocky headland overlooking the Atlantic Ocean in the Abura-Asebu-Kwamankese (A-A-K) District. According to the 2000 population census, Moree has a total population of 17,761. Out of this 8,577 are males whilst 9,184 are females. Marine fishing and fish processing are the main occupations in the community, though as the town has grown the services industry including retailing and informal artisanal activities, have expanded considerably (Marquette et al., 2002).

\subsection{Data Collection}

Primary data was collected by means of a number of participatory methods, which included visualizations, poverty profiles, mappings, focus group discussions, personal interviews and participant observations. The focus group discussions were held at the beginning of the study. Two focus groups were organised in each community, an extra one some representatives of government at the local level. The questions for the focus group discussions were generated based on extensive study of secondary data such as newspapers and other reports on the study areas, as well as through observations. Some of the questions were developed or altered as the discussions progressed. Questions for the focus group discussions examined perceptions of poverty, socio-economic and environmental concerns, dependence on coastal natural resources, knowledge on institutions involved in managing natural resources in the communities as well as extent of community involvement. The discussions and audio recordings generated a lot of data which was analysed qualitatively using thematic analysis. This method involves "identifying, analyzing and reporting patterns (themes) within data" (Braun \& Clarke, 2006:79). Information from the focus group discussions was also important in creating questions for the Likert Scales.

\subsubsection{Personal Interviews}

In all 304 women; 151 in Bortianor and 153 in Moree were involved in the personal interviews. The target population was women living in the coastal zone of Ghana above sixteen years (16) years. This lower limit was chosen because there was the need to interview women who could appreciate the issues at stake. The actual dwelling compounds that were visited for the interviews were identified through purposive sampling, in an attempt to reach and to interview women with different backgrounds. The final questionnaire, which also doubled as an interview guide depending on whether the respondent could read and write contained both open ended and closed questions and was made up of nine sections.

Likert scales were used to assess respondents' environmental attitudes. This scaling technique used statements that required the respondents to indicate the extent to which they agreed or disagreed with the statements. The measurement scale was explained to the respondents to avoid any confusion. The questions for this section were developed using information from the focus group discussions and an extensive review of literature which resulted in the selection of three statements from the New Ecological Paradigm (Dunlop et al., 2000), which were found to be relevant to the study.

The study prioritised respondents' environmental concerns through the judgment of severity placed by respondents on certain environmental issues (Quah et al., 2003). The paired comparison methodology measures environmental values and concerns of respondents by providing a clear order of the relative priority they place on coastal natural resources. An added advantage is that apparent preference intransitivities or inconsistent choice patterns are easily observable (Chuenpagdee, 1998). The pairs were presented to the respondents who were asked to choose the environmental concern they saw as most critical.

\subsubsection{Participant Observations}

The method used was passive participation, which means that the researcher was present at the area of activity but was more of a bystander or spectator. From the beginning of the study, throughout the study period many visits were made to both Bortianor and Moree. This enabled the researcher to identify who the key players of the community were and determine how to gain access into the communities. In order to understand the context in which to interpret people's comments, the researcher also attended some local events, visited local markets and public places and also met with some local government employees. Behaviours of randomly selected respondents were observed to assess the extent to which their actual behaviours agreed with their professed behaviours.

\subsection{Analyses}

Simple frequencies and cross-tabulations dependent and independent variables were analysed quantitatively using Statistical Package for the Social Sciences (SPSS) version 16. Data from the factual questions were presented in 
frequency tables showing the raw numbers and in terms of percentages of the total. Descriptive information was also presented in tables.

In developing Likert-style questions, each question must have a similar psychological weight and direction in the respondent's mind. This method has been used quite extensively in assessing attitudes, including environmental attitudes. The challenge however, is developing the right questions that can be easily understood by the respondents and that can also effectively assess their environmental attitudes. For this study the respondents made a variety of responses in the form of a five point scale ranging from strongly agree (SA), agree (A), indifferent (I), disagree (D), strongly disagree (SD). A numeric score was given to each item in order to reflect the degree to which the respondent agreed and disagreed with the item. The scores were totalled to measure the attitude of the respondent. The maximum score was 75 (5X15) and the minimum 15 (5X1), since no statements were left blank. The scores were then grouped into two categories. Scores ranging from 15 to 45 represented a negative attitude whilst scores from 46 to 75 a positive attitude. On the other hand a four point Likert scale was used to measure behaviour. The middle point was removed since these are actual behaviours and respondents had to have either participated in the activities or not.

The total score gave some idea of the strength of a respondent's attitude. The items of statements all had approximately the same level of importance (size) to the respondent, and are all more or less talking about the same concept (direction), which concept the scale is trying to measure. The "direction" of the statements was mixed up, to make sure statements were carefully read, and the informant had to consider their answers carefully. A simple way of evaluating paired comparison data is to use the preference score for each item which is the number of times the respondent prefers that item over other items in the choice set (Peterson \& Brown, 1998). The paired comparison questions were thus analysed in a straight-forward fashion by examining a matrix of preferences and calculating an arithmetic average of the preference for each value across all other values with which it was paired. This is because scaling the scores would have not produced different results (Neuman \& Watson, 1993). Where no circular triads were produced, the result showed a clear ordering of environmental values of women towards coastal natural resources.

\section{Results}

\subsection{Socio-Economic Background of Respondents}

About half of the respondents interviewed were below the age of 40 years (Table 3). More respondents from Bortianor were married. Marriage is an inherent part of the fisheries industry, which is reflected in the gender division of labour: men fish and women trade. The right of a wife to buy fish through a husband or son is thus an important institution in the fishing economy (Overå, 1998; Marquette et al., 2002).

As is expected, fishing industry employed the highest number of women, although the percentage $(67.2 \%)$ was higher in Moree. The vital role played by women can be especially seen during the lean fishing season. When there are problems with the effective processing of fish, there is a remarkable decrease in the availability of fish in the market and an increase in prices. About $18.3 \%$ of respondents in Bortianor as compared to $12.5 \%$ in Moree considered themselves unemployed. Many of these used to be involved in the post harvest fishing industry and had lost their initial investment as a result of dwindling fish catch. Whilst petty trading used to be a secondary occupation for most, it is becoming increasingly profitable to sell along the main roads, to visitors and tourists than to depend on fish for their livelihood.

\subsubsection{Respondents' Perceptions on Poverty and Vulnerability}

Poverty levels among the post-harvest fisheries sector in Ghana is estimated to be $29 \%$. Although this figure is lower than the food and export crops sectors it is still significant (NDPC, 2003). The poor rely heavily on the fisheries post-harvest sector because it is an easy sector to enter with few barriers to stop the unskilled engaging in activities such as labouring and petty- trading (IMM, 2004). Activities include carrying fish around from place to another, sorting by-catch from canoes and trawlers, selling small quantities of fish to other poor consumers. These often make up the majority of people in the post-harvest sector (IMM, 2004). In order to understand their perceptions of poverty, the respondents were first asked if they thought themselves as being poor. More than half of the respondents described themselves as poor, $67.1 \%$ in Bortianor and $72 \%$ in Moree, which could again be a reflection of the growing economic instability in the post-harvest fisheries sector. The study also asked respondents to cite the four contributory factors of poverty. Interestingly, although issues relating to environment and natural resources did not seem to be priority issues, it was mentioned in both areas. Most of their concerns had to do with their ability to take care of themselves and their families. Decreasing fish catch and food insecurity were ranked highest. 
Table 3. Age, marital status and educational levels of respondents

\begin{tabular}{lllll}
\hline & \multicolumn{2}{l}{ Bortianor } & \multicolumn{2}{l}{ Moree } \\
\hline Age & $\mathrm{N}$ & $\%$ & $\mathrm{~N}$ & $\%$ \\
\hline 16-20 years & 12 & 7.9 & 20 & 13.1 \\
21-25 years & 20 & 13.2 & 25 & 16.3 \\
26-30 years & 15 & 9.9 & 21 & 13.7 \\
31-35 years & 19 & 12.5 & 12 & 7.8 \\
36-40 years & 21 & 13.9 & 7 & 4.6 \\
41-45 years & 19 & 12.6 & 17 & 11.1 \\
46-50 years & 14 & 9.3 & 18 & 11.8 \\
51-55 years & 8 & 5.3 & 11 & 7.2 \\
$>56$ years & 11 & 7.3 & 19 & 12.4 \\
Do not know & 12 & 7.9 & 3 & 2.0 \\
\hline Total & $\mathbf{1 5 1}$ & $\mathbf{1 0 0}$ & $\mathbf{1 5 3}$ & $\mathbf{1 0 0}$ \\
\hline Marital Status & & & & \\
\hline Single & 19 & 12.6 & 37 & 24.2 \\
Married & 114 & 75.5 & 93 & 60.8 \\
Separated/Divorced & 11 & 7.3 & 16 & 10.5 \\
Widowed & 7 & 4.6 & 7 & 4.6 \\
\hline Total & $\mathbf{1 5 1}$ & $\mathbf{1 0 0}$ & $\mathbf{1 5 3}$ & $\mathbf{1 0 0}$ \\
\hline Education & & & & \\
\hline None & 84 & 55.6 & 94 & 61.4 \\
Primary & 44 & 29.1 & 32 & 20.9 \\
Middle school & 8 & 5.3 & 6 & 3.9 \\
JHS & 8 & 5.3 & 16 & 10.5 \\
SHS & 2 & 1.3 & 4 & 2.6 \\
Vocational/tech & 3 & 2.0 & 1 & 0.7 \\
University & 2 & 1.3 & - & - \\
\hline Total & $\mathbf{1 5 1}$ & $\mathbf{1 0 0}$ & $\mathbf{1 5 3}$ & $\mathbf{1 0 0}$ \\
\hline & & & & \\
\hline
\end{tabular}

\subsubsection{Access to Basic Amenities}

Poor access to some basic amenities like potable water and good sanitation all influence the environmental attitudes of respondents. For example structures for rubbish collection in the communities were virtually non existent. In addition only $6 \%$ of respondents in Bortianor and $15 \%$ of respondents in Moree had access to toilets in their homes or compounds. Majority of the respondents were aware of the fact that beach defecation was wrong and had some awareness of its impacts but insisted they did it because if a lack of other options. Most of them expected the government through the District Assemblies to provide them with places of convenience as well as other basic amenities.

\subsection{Environmental Concerns}

Individual expression of environmental concern is often influenced by their perception of the biophysical environment. Respondent's local environmental concern was high. The choices made by respondents were analysed in a straight-forward fashion. $20 \%$ of the results in Bortianor as compared to $16 \%$ of the results in Moree were inconsistent. The results could thus be used (Figure 2). 


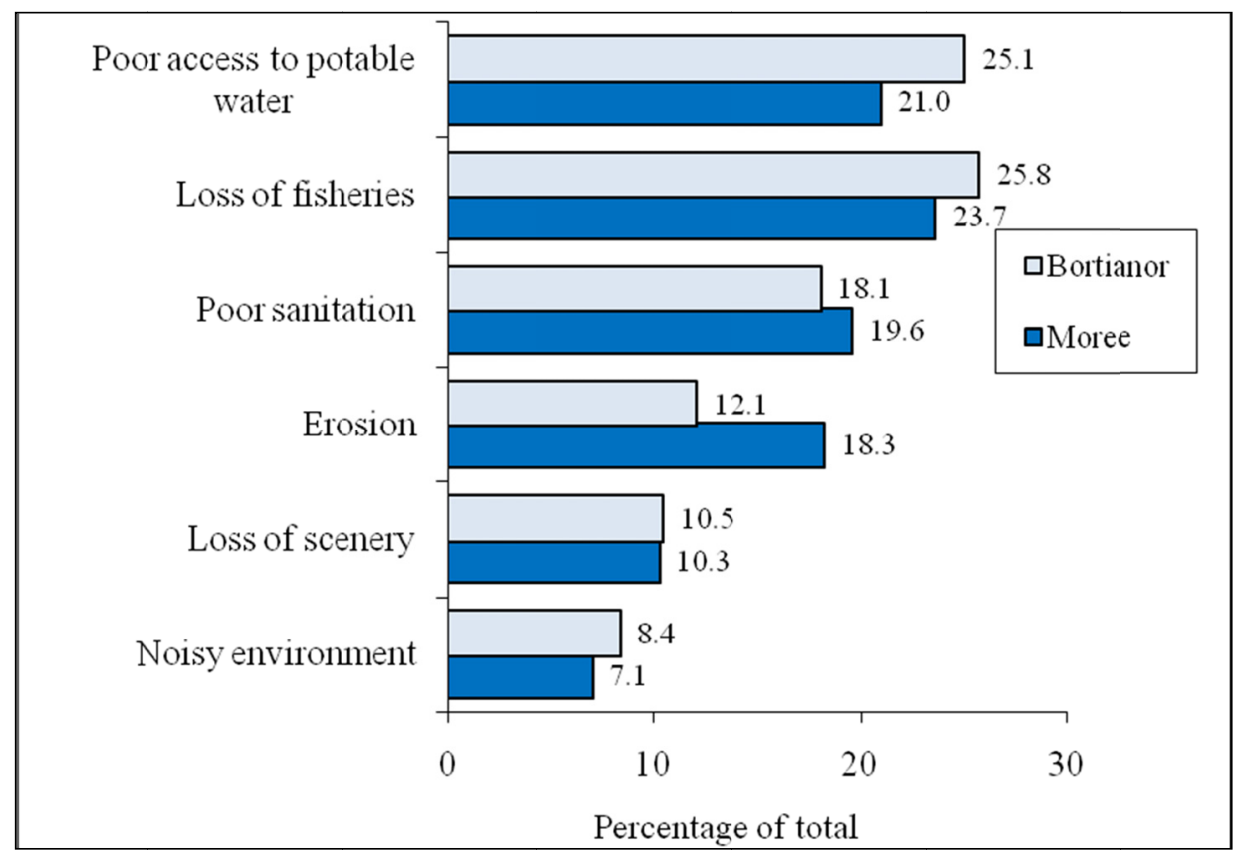

Figure 2. Environmental concerns in study areas

Poor access to potable water and the loss of fisheries were high priority areas in both communities. These were followed by poor sanitation. Coastal Erosion was judged as a bigger environmental problem in Moree as compared to Bortianor.

\subsection{Attitudes and Behaviour of Respondents Towards Trends of Natural Resource Degradation}

The constructions of the attitudinal questions were based on specific, identified problems affecting natural resources in the area. In addition, Three of the 15 statements were adapted from the New Ecological Paradigm (Dunlop et al., 2000) to suit the local setting (Tables 4 and 5). The statements assess attitudes towards natural resources through:

- Sanitation, pollution, loss of fish and natural resource use (Questions 1, 2, 3, 6, 8, 9, 10, 11, and 13).

- Anti anthropocentric (note 1) attitudes (Questions 5, 12, and 15).

- Institutions for managing coastal natural resources (Questions 4, 7, and 14).

The scale achieved adequate internal consistency with a Cronbach's (1951) Alpha reliability coefficients 0.729 in Bortianor and 0.735 in Moree. This showed that the scales developed were reliable and valid. There were few exceptions however. For example in Bortianor more than half of respondents agreed with the statement that it is okay to throw rubbish on the beach if you are poor (Tables 4 and 5). Their strong disagreement to the statement that plants and animals have as much right to exist as humans is also noteworthy. More than $20 \%$ were undecided concerning the questions humans have a right to modify the natural environment to suit their needs, the natural resources cannot get depleted, people who pollute the beaches and the surrounding mangroves should pay to clean it. 
Table 4. Environmental attitudes of respondents in Bortianor

\begin{tabular}{|c|c|c|c|c|c|}
\hline Items in scale & SA $(\%)$ & $\mathrm{A}(\%)$ & $\mathrm{I}(\%)$ & $\mathrm{D}(\%)$ & $\mathrm{SD}(\%)$ \\
\hline $\begin{array}{l}\text { 1. The coastal zone is being degraded by indiscriminate dumping of refuse } \\
\text { and defecation. }\end{array}$ & 39.7 & 45.0 & 5.3 & 9.3 & 0.7 \\
\hline 2. It is okay to throw rubbish on the beach if you are poor. & 10.9 & 34.4 & 9.9 & 29.5 & 15.3 \\
\hline 3. All households in the communities should have toilets and bathrooms. & 56.3 & 35.1 & 3.3 & 4.6 & 0.7 \\
\hline $\begin{array}{l}\text { 4. Resource users should be involved in the management of coastal natural } \\
\text { resources. }\end{array}$ & 41.1 & 31.8 & 7.3 & 18.5 & 1.3 \\
\hline $\begin{array}{l}\text { 5. Humans have a right to modify the natural environment to suit their } \\
\text { needs. }\end{array}$ & 26.5 & 42.4 & 22.5 & 6.6 & 2.0 \\
\hline $\begin{array}{l}\text { 6. Outdoor defecation and indiscriminate waste disposal along the beach } \\
\text { cause diseases. }\end{array}$ & 59.6 & 27.2 & 4.6 & 7.3 & 1.3 \\
\hline $\begin{array}{l}\text { 7. Management of coastal natural resources is the sole responsibility of the } \\
\text { government }\end{array}$ & 29.8 & 39.1 & 15.9 & 14.6 & 0.7 \\
\hline $\begin{array}{l}\text { 8. Only unconcerned and uncommitted citizens dump garbage and defecate } \\
\text { along the beaches. }\end{array}$ & 5.6 & 30.4 & 7.3 & 39.5 & 17.3 \\
\hline $\begin{array}{l}\text { 9. People who pollute the beaches and the surrounding mangroves should } \\
\text { pay to clean it. }\end{array}$ & 6.0 & 31.1 & 21.9 & 34.4 & 6.6 \\
\hline 10. Fishing with dynamite and nets with small mesh size is not good & 58.3 & 24.5 & 2.0 & 13.9 & 1.3 \\
\hline 11. The natural resources cannot get depleted & 4.0 & 41.7 & 26.5 & 27.8 & 0 \\
\hline 12. Plants and animals have as much right to exist as humans. & 2.0 & 23.2 & 7.3 & 53.6 & 13.9 \\
\hline $\begin{array}{l}\text { 13. If the current degradation of natural resources continues we will soon } \\
\text { experience a major ecological catastrophe. }\end{array}$ & 29.8 & 54.3 & 10.6 & 4.6 & 0.7 \\
\hline $\begin{array}{l}\text { 14. Priority in resource allocation should be given to activities that create } \\
\text { greatest economic returns even if it may harm the environment. }\end{array}$ & 9.9 & 47.5 & 9.3 & 32.5 & 0.8 \\
\hline 15. Humans were meant to rule over the rest of nature. & 4.0 & 53.6 & 11.3 & 28.8 & 1.3 \\
\hline
\end{tabular}

SA-Strongly agree, A-agree, I-indifferent, D-disagree, SD-strongly disagree.

Table 5. Environmental attitudes of respondents in Moree

\begin{tabular}{|c|c|c|c|c|c|}
\hline Items in scale & $\begin{array}{l}\text { SA } \\
(\%)\end{array}$ & $\begin{array}{l}\text { A } \\
(\%)\end{array}$ & $\begin{array}{l}\text { I } \\
(\%)\end{array}$ & $\begin{array}{l}\mathrm{D} \\
(\%)\end{array}$ & $\begin{array}{l}\text { SD } \\
(\%)\end{array}$ \\
\hline $\begin{array}{l}\text { 1. The coastal zone is being degraded by indiscriminate dumping of refuse and } \\
\text { defecation. }\end{array}$ & 40.5 & 43.1 & 5.2 & 10.5 & 0.5 \\
\hline 2. It is okay to throw rubbish on the beach if you are poor. & 13.7 & 35.8 & 10.4 & 25.5 & 14.6 \\
\hline 3. All households in the communities should have toilets and bathrooms. & 16.3 & 35.1 & 13.3 & 34.6 & 0.7 \\
\hline 4. Resource users should be involved in the management of coastal natural resources. & 38.6 & 32.7 & 7.2 & 20.3 & 1.3 \\
\hline 5. Humans have a right to modify the natural environment to suit their needs. & 24.2 & 42.5 & 23.5 & 7.8 & 2.0 \\
\hline 6. Outdoor defecation and indiscriminate waste disposal along the beach cause diseases. & 58.8 & 27.5 & 4.6 & 7.8 & 1.3 \\
\hline 7. Management of coastal natural resources is the sole responsibility of the government & 27.5 & 41.2 & 15.0 & 15.7 & 0.7 \\
\hline $\begin{array}{l}\text { 8. Only unconcerned and uncommitted citizens dump garbage and defecate along the } \\
\text { beaches. }\end{array}$ & 11.1 & 47.1 & 7.2 & 24.2 & 10.5 \\
\hline $\begin{array}{l}\text { 9. People who pollute the beaches and the surrounding mangroves should pay to clean } \\
\text { it. }\end{array}$ & 5.2 & 35.3 & 19.6 & 33.3 & 6.5 \\
\hline 10. Fishing with dynamite and nets with small mesh size is not good & 56.2 & 28.1 & 2.0 & 12.4 & 1.3 \\
\hline 11. The natural resources cannot get depleted & 5.2 & 39.9 & 26.1 & 28.8 & 0.0 \\
\hline 12. Plants and animals have as much right to exist as humans. & 10.7 & 29.0 & 9.8 & 39.8 & 10.7 \\
\hline $\begin{array}{l}\text { 13. If the current degradation of natural resources continues we will soon experience a } \\
\text { major ecological catastrophe. }\end{array}$ & 28.1 & 54.9 & 11.1 & 5.2 & 0.7 \\
\hline $\begin{array}{l}\text { 14. Priority in resource allocation should be given to activities that create greatest } \\
\text { economic returns even if it may harm the environment. }\end{array}$ & 1.3 & 23.5 & 17.8 & 44.2 & 13.2 \\
\hline 15. Humans were meant to rule over the rest of nature. & 4.6 & 54.9 & 10.5 & 28.1 & 2.0 \\
\hline
\end{tabular}

SA- Strongly agree, A- agree, I- indifferent, D- disagree, SD- strongly disagree. 
The scales reflect negative and positive environmental attitudes. The higher the number, the stronger is the intention to perform the behaviour. Hence in this study a person with a negative attitude has low score and is least ready to support natural resources management initiatives. The environmental attitudes of respondents in both areas towards natural resource degradation were overwhelmingly positive with $94.7 \%$ of respondents in Bortianor compared to $90.8 \%$ in Moree exhibiting positive attitudes. From the chi-squared computed p-value obtained was 0.271. Thus there was no statistical significant difference between the environmental attitudes of the respondents in Bortianor and Moree.

\subsubsection{Actual Participation in Some Environmental Behaviours}

Actual behaviours were measured with respondents indicating their how often they participated in five activities (Table 6). To make this as practical as possible, the selected behaviours were simple everyday activities easily understood by the respondents. Some of these were also rephrased from the questions in Tables 4 and 5. In addition behaviours of randomly selected respondents were observed to assess the extent to which their actual behaviours agreed with their professed behaviours.

Table 6. Respondents' participation in actual environmental behaviours

\begin{tabular}{lcccccccc}
\hline \multicolumn{1}{c}{ Behaviour } & \multicolumn{3}{c}{ Bortianor } & \multicolumn{5}{c}{ Moree } \\
\hline Do you... & $\mathrm{Y}$ & $\mathrm{S}$ & $\mathrm{R}$ & $\mathrm{N}$ & $\mathrm{Y}$ & $\mathrm{S}$ & $\mathrm{R}$ & $\mathrm{N}$ \\
\hline 1. Throw rubbish in gutters, bushes and on the beach? & 56.3 & 35.7 & 4.9 & 3.1 & 64.8 & 18.5 & 5.2 & 11.5 \\
2. Defecate in on the beach and its surroundings? & 58.6 & 29.3 & 6.2 & 5.9 & 61.0 & 27.1 & 10.2 & 1.7 \\
$\begin{array}{l}\text { 3. Encourage friends and family to keep their surroundings } \\
\text { clean? }\end{array}$ & 20.4 & 21.3 & 26.5 & 31.8 & 17.5 & 35.0 & 32.6 & 14.9 \\
Participate in tree planting and clean up exercises? & 22.7 & 34.5 & 17.0 & 25.8 & 27.2 & 40.8 & 20.7 & 11.3 \\
$\begin{array}{l}\text { Buy fish you know is caught with small nets or dynamite? } \\
\text { 6. Cut mangroves and other trees along the beaches for fuel }\end{array}$ & 31.1 & 20.3 & 31.0 & 17.6 & 37.1 & 23.2 & 11.4 & 28.3 \\
wood? & 22.1 & 28.2 & 19.1 & 30.6 & 15.1 & 20.0 & 28.3 & 36.6 \\
\hline
\end{tabular}

Y: Yes; S: Sometimes; R: Rarely; N: No.

More than $80 \%$ of respondents in both areas disposed of their domestic and human waste on the beaches. In addition more than half had at one time or the other bought fish that they knew was caught by unapproved means. Similarly, most respondents admitted they used the beaches as places of convenience and rubbish disposal although they knew it was wrong. However they still did it, sometimes because of the lack of other alternatives. Others strongly disagreed that those who dump rubbish indiscriminately should be punished, but not until there were suitable facilities provided by the District Assembly. Some disagreed that sand winning should be illegal because they argued there were no jobs. There were also some who said that it was wrong to fish with dynamite or other illegal means and yet still bought fish caught this way because they still had to feed their families. Such respondents would generally exhibit positive environmental attitudes yet negative environmental behaviour.

Majority of the respondents also believed that the management of coastal natural resources is the sole responsibility of the government and its agencies such as the District Assemblies and the area/town councils. They believed that since they paid some form of tax directly or indirectly these monies should be used in cleaning the communities, for management programmes and to provide basic infrastructure.

\subsection{Key Elements Required in the Translation of Attitudes Into Behaviour}

An analysis of the relationship between education and environmental attitudes showed that education affected the attitudes of respondents towards coastal natural resources positively. Hence knowledge and education (formal, non-formal and informal) remain effective routes to attitude change (Mehta \& Heinen 2001; Dolisca et al., 2007). Environmental awareness which may be created through various programmes at various levels, influences how people perceive and interact with coastal natural resources. It also helps to create environmentally positive behaviour in people. However environmental education programmes cannot be implemented in isolation. For example there is substantial evidence to show that poor people will increase their dependence on natural sources to survive (Lawson et al., 2012; Lawson \& Bentil, 2014), which will lead to further degradation irrespective of the levels of environmental education received. Hence addressing environmental as well as socio-economic concerns 
such as the provision of sanitation facilities, potable water, alternative livelihoods as well as the enforcement of existing laws and equipping relevant institutions to work effectively all influence behavioural intensions and must be addressed simultaneously. This will help natural resource users to translate environmentally positive attitudes into environmentally positive behaviour (Figure 3 ).

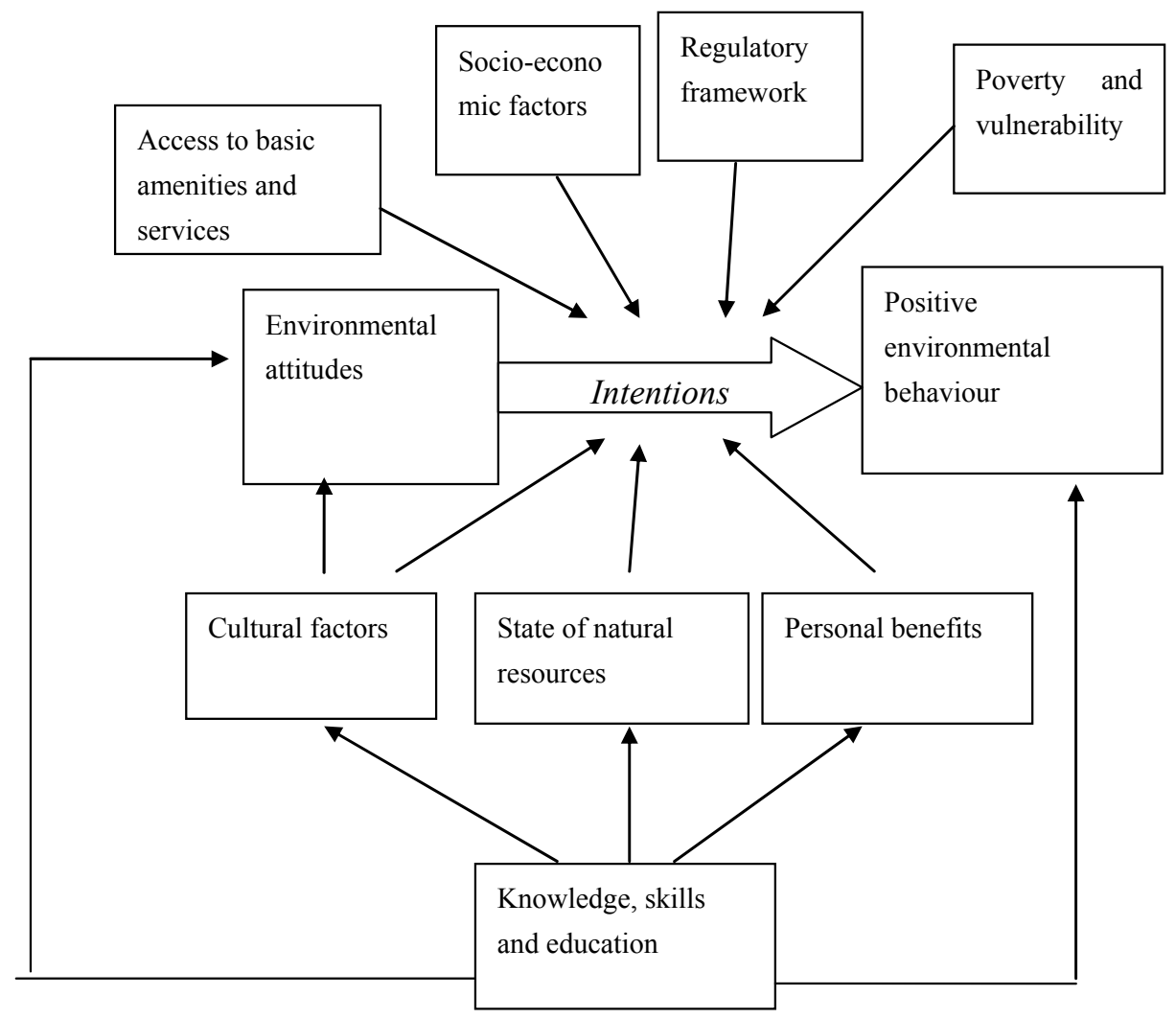

Figure 3. Relationship between attitudes and behaviour

\section{Discussion}

Whilst the results presented in this paper cannot be generalized they have provided a snapshot of the nature of environmental attitudes among some selected residents in two coastal communities in Ghana. The results presented have also critically examined the often expressed assumption that positive environmental attitudes result in positive behaviour. This paper has examined the socio-economic milieu in which environmental decisions are made. It has assessed the main environmental concerns of respondents as well their environmental attitudes and behaviours. Based on the findings, it can be concluded that efforts to manage the coastal zone may be more effective when the socio-economic background of resource users (Cinner \& Pollnac, 2004) as well as how they prioritise their environmental concerns are understood. Environmental education remains important. However the reality is that whilst some level of awareness could lead to positive attitudes it does not always lead to positive environmental behaviour. Hence concentrating only on the creation of positive attitudes is not the solution to the challenges facing the effective management of coastal natural resources. Equal effort must also be places on the factors that influence the translation of attitudes into behaviour, which in this paper were identified to include improved access to basic amenities and infrastructure, livelihood options and the right governance regimes.

The Sustainable Livelihoods Approach (SLA) offers a way of addressing coastal livelihood complexities whilst providing an entry point to supporting coastal poverty and livelihood change (Campbell et al., 2006; Badjeck, 2010). The approach embraces the complexity of rural livelihoods from the perspective of the poor. It takes the poor as the centre of the development process because they are the ones most in need of support and it provides a mechanism for enhancing empowerment of the poor (Campbell et al., 2006). The approach provides a framework for understanding and guiding policy-making in coastal zone whilst improving the well-being of community 
members, enabling them to expend more energy in other activities such being actively involved in community initiatives to manage coastal natural resources (Schulte et al., 2013)

Another crucial yet often understated requirement for the successful translation of positive attitudes into behaviour is an effective governance regime. This can be seen from the percentage of respondents who believe that the management of coastal zone is the responsibility of the government and its agencies. Access to, and use of natural resources by individuals, households and communities are influenced by policies, institutions and the context in which individuals, households and communities live (Prowse \& Chimhowu, 2007). The lack of a comprehensive national coastal zone management policy means that the management of the coastal environment depends on laws and policies from other sectors as well as traditional governance systems. Local governments often do not have enough capacity, funds and authority to implement an integrated coastal management. This has led to a gap between the development of the laws and policies and their enforcement (Lawson et al., 2010). Enforcement of exixtsing laws is critical for the effective management of coastal resources. When governance regimes are effective, they challenge resource users to take responsibility for their actions and includes more of their knowledge and perceptions (Mahona et al., 2008).

Respondents' behaviours were in conflict with their professed attitudes (Kollmuss \& Agyeman, 2002). The findings of this study are similar with Kotey (1998) who studied the attitudes of residents of Cape Coast towards beach sanitation. She also found out that that generally people expressed positive attitudes. These positive attitudes did not necessarily translate into good conservation practices; people's beliefs are sometimes in conflict with their actions. According to Schultz \& Zelezny (1999), one viable explanation for why positive environmental attitudes exist in a "developing" setting is that culture (defined as knowledge, attitudes, values, beliefs, and behaviours shared by a group of people that are communicated from one generation to the next), and held values play an important role in determining environmental attitudes. This could cause a significant discrepancy between people's attitudes and their actual behaviour (Chan, 1996). As already mentioned, an understanding of the complexities of the interrelationships between human activity and the natural environment is therefore necessary for the improvement of environmental quality.

In conclusion positive environmental attitudes do not necessarily result in positive behaviour as this study has shown. Factors that cause environmental degradation in the coastal environment need to be addressed simultaneously. Education and awareness on environmental issues should go hand-in-hand with the provision of infrastructure, livelihood options and the right governance regimes. Since coastal natural resources serve as a source of well-being and livelihood for many of the coastal residents its management must be carried out in partnership with major groups such as local communities. These communities are not homogenous and as such the needs of different groups such as women and the poor must be taken into consideration. The strategies that will be most effective in managing coastal natural resources are those that seek to reduce poverty, create environmental awareness and provide improved access to social amenities and infrastructure and provide effective governance systems that ensure that those who pollute the coastal environment are penalised.

\section{References}

Adger, W. N., Hughes, T. P., Folke, C., Carpenter, S. R., \& Rockström, J. (2005). Social-ecological resilience to costal disasters. Science, 309(5737), 1036-1039. http://dx.doi.org/10.1126/science.1112122

African Development Bank. (2011). Gender, Poverty and Environmental Indicators on African Countries. Economic and Social Statistics Division Statistics Department, African Development Bank. Belvédère Tunis, Tunisia. 312 pages

Ajzen, I., \& Driver, B. L. (1992). Contingent value measurement: on the nature and meaning of willingness to pay. Journal of Consumer Psychology, 1(4), 297-316. http://dx.doi.org/10.1016/S1057-7408(08)80057-5

Badjeck, M. C., Allison, E. H., Halls, A. S., \& Dulvy, N. K. (2010). Impacts of climate variability and change on fishery-based livelihoods. Marine Policy, 34(3), 375-383. http://dx.doi.org/10.1016/j.marpol.2009.08.007

Barr, S., \& Gilg, A.W. (2007). A conceptual framework for understanding and analyzing attitudes towards environmental behaviour. Geografiska Annaler Series B, 8(4), 361-379. http://dx.doi.org/10.1111/j.1468-04 67.2007.00266.x

Braun, V., \& Clarke, V. (2006). Using thematic analysis in psychology. Qualitative Research in Psychology, 3, 77-101. http://dx.doi.org/10.1191/1478088706qp063oa

Brian, J. (2003). Integrated Coastal Resource Management: A Prescription for Sustainable development. Electronic Green Journal, 1(19). 
Campbell, J., Whittingham, E., \& Townsley, P. (2006). Responding to coastal poverty: should we be doing things differently or doing different things? In C. T. Hoanh, T. P. Tuong, J .W. Gowing, \& B. Hardy (Eds.), Environment and Livelihoods in Tropical Coastal Zones (pp. 230-257). CABI Publishing, Wallingford UK and Cambridge MA USA.

Chan, K. W. (1996). Environmental attitudes and behaviour of secondary school students in Hong Kong. The Environmentalist, 16, 297-306. http://dx.doi.org/10.1007/BF02239656

Chuenpagdee, R. (1998). Scales of relative importance and damage schedules: non-monetary valuation approach for Natural Resource Management. Ph.D. Dissertation submitted to the Faculty of Graduate Studies (Resource Management and Environmental Studies), University of British Columbia. 269 pages.

Cinner, J. E., \& Pollnac, R. B. (2004). Poverty, perceptions and planning: why socio-economic matter in the management of Mexican Reefs. Oceans and Coastal Management, 47, 479-493. http://dx.doi.org/10.10 16/j.ocecoaman.2004.09.002

Coleman, T. L., Manu, A., \& Twumasi, Y. A. (2005). Application of landsat data to a base-line ecological study of mangrove vegetation along the coast of Ghana. In Proceedings of the $31^{\text {st }}$ International Symposium on Remote Sensing of Environment (ISRSE) - Global Monitoring for Sustainability and Security Conference. The International Society of Photogrammetry and Remote Sensing (ISPRS). June 20-21. Saint Petersburg, Russia Federation.

d'Aquino, P., \& Bah, A. (2013). A Participatory Modeling Process to Capture Indigenous Ways of Adaptability to Uncertainty: Outputs From an Experiment in West African Drylands. Ecology and Society, 18(4). http://dx.doi.org/10.5751/ES-05876-180416

Directorate of Fisheries. (2003). Ghana: post-harvest fisheries overview. Directorate of Fisheries, Ministry of Food and Agriculture, Ghana. Brightsea Press Ltd, Exeter, UK. 81 pages.

Dolisca, F., Carter, D. R., McDaniel, J. M., Shannon, D. A., \& Jolly, C. A. (2006). Factors influencing farmers' participation in forestry management programs: A case study from Haiti. Forest Ecology and Management, 236, 324-331. http://dx.doi.org/10.1016/j.foreco.2006.09.017

Dunlap, R. E., Van Liere, K., Mertig, A., \& Jones, R. E. (2000). Measuring endorsement of the New Ecologial Paradigm: a revived NEP Scale. Journal of Social Issues, 56, 425-442. http://dx.doi.org/10.1111/002 2-4537.00176.

Eisenhardt, K. M. (1989). Building theories from case study research. Academy Management Review, 14(4), 532-550. http://escholarship.org/uc/item/6kp8g491.

English, B. (2003), Integrated coastal resource management: A prescription for sustainable development. Electronic Green Journal, 1 (19). Retrieved August 27, 2008, from http://escholarship.org/uc/item/6k $\mathrm{p} 8 \mathrm{~g} 491$.

EPA. (2011). Ghana's Second National Communication, under the United Nations Framework Convention on Climate Change, Environmental Protection Agency, Accra. 168pp.

Ferrol-Schulte, D., Wolff, M., Ferse, S., \& Glaser, M. (2013). Sustainable Livelihoods Approach in tropical coastal and marine social-ecological systems: A review Marine Policy, 42, 253-258 http://dx.doi.org/10.1016/j.marpol.2013.03.007

Fiallo, E., \& Jacobson, S. (1995). Local communities and protected areas: attitudes of rural residents towards conservation and Machalilla National Park, Ecuador. Environmental Conservation, 22, 241-249. http://dx.doi.org/10.1017/S037689290001064X

Fishbein, M., \& Ajzen, I. (1975). Belief, attitude, intention and behaviour: an introduction to theory and research. Addison-Wesley Publishing, Reading, MA.

Ghana Statistical Service (GSS). (2009). Ghana at a Glance 2009. GSS, Accra.

Government of Ghana (GoG). (2010). Medium Term National Development Policy Framework: Ghana Shared Growth and Development Agenda (GSGDA I), 2010-2013 Volume I: Policy Framework. NDPC, Accra.

Hill, C. (1998). Conflicting attitudes towards elephants around the Budongo Forest Reserve, Uganda. Environmental Conservation, 25(3), 244-250. http://dx.doi.org/10.1017/S0376892998000307 
Hines, J. M., Hungerford, H. R., \& Tomera, A. N. (1987). Analysis and synthesis of research on responsible environmental behaviour: A meta-analysis. Journal of Environmental Education, 18(2), 1-8. http://dx.doi.org/10.1080/00958964.1987.9943482

IMM. (2004). A Framework for Linking Poverty to Policy in the Post-Harvest Fisheries Sector. Output from the Post-Harvest Fisheries Research Programme Project R8111. IMM Ltd, Exeter, UK. 4 pages

Kaiser, F. G., Hübner, G., \& Bogner, F. X. (2005). Contrasting the theory of planned behavior withthe value-belief-norm model in explaining conservation behavior. Jornal of Applied Social. Psychology, 35, 2150-70. http://dx.doi.org/10.1 111/j.1559-1816.2005.tb02213.x

Kollmuss, A., \& Agyeman, J. (2002). Mind the gap: why do people act environmentally and what are the barriers to pro-environmental behaviour? Environmental Education Research, 8(3), 239-260. http://dx.doi.org/10.108 $0 / 13504620220145401$

Kotey, V. D. (1998). Attitude towards environmental degradation of the Cape Coast Beach. M. Ed. Thesis. University of Cape Coast, Ghana. 150 pages

Lawson, E. T., \& Bentil, G. (2014). Shifting sands: changes in community perceptions of mining in Ghana. Journal of Environment, Development and Sustainability, 16(1), 217-238. http://dx.doi.org/10.1007/s10 668-013-9472-y

Lawson, E. T., Gordon, C., \& Schluchter, W. (2012). The Dynamics of Poverty Environment Linkages in the Coastal Zone of Ghana. Oceans and Coastal Management, 67, 30-38. http://dx.doi.org/10.1016/j.oce coaman.2012.05.023

Lawson, E. T., Schluchter, W., \& Gordon, C. (2010). Using the paired comparison methodology to assess environmental values in the coastal zone of Ghana. Journal of Coastal Conservation, 14(3), 231-238. http://dx.doi.org/10.1007/s11852-010-0096-1

Lepp, A. (2007). Residents' attitudes towards tourism in Bigodi village, Uganda. Tourism Management, 28 , 876-885. http://dx.doi.org/10.1016/j.tourman.2006.03.004

Levine, D. S., \& Strube, M. J. (2012). Environmental attitudes, knowledge, intentions and behaviors among college students. Journal of Social Psychology, 152(3), 308-326. http://dx.doi.org/10.1080/00224 545.2011 .604363

Mahona, R., McConneya, P., \& Royb, R. N. (2008). Governing fisheries as complex adaptive systems Marine Policy, 32, 104-112. http://dx.doi.org/10.1016/j.marpol.2007.04.011

Marquette, C. M., Koranteng, K. A., Overå, R., \& Bortei-Doku Aryeetey, E. (2002). Small-scale fisheries, population dynamics and resource use in Africa: The Case of Moree, Ghana. AMBIO, 31(4), 324-336.

Mehta, J. N., \& Kellert, S. R. (1998). Local attitudes toward community-based conservation policy and programmes in Nepal: a case study in the Makalu-Barun Conservation Area. Environmental Conservation, 25(4), 320-333. http://dx.doi.org/10.1017/S037689299800040X

Mehta, J., \& Heinen, J. (2001). Does community-based conservation shape favorable attitudes among locals? An empirical study from Nepal. Environmental Management, 8(2), 165-177. http://dx.doi.org/10.1007/s002 670010215

National Development Planning Commission. (2003). Ghana Poverty Reduction Strategy 2003-2005. An agenda for growth and prosperity. Volume I: analysis and policy statement. Government of Ghana and National Development Planning Commission, Accra, Ghana.

Nelson, F., \& Agrawal, A. (2008). Patronage or participation? Community-Based natural resource management reform in Sub-Saharan Africa. Development and Change, 39, 557-585. http://dx.doi.org/10.1111/j.1467-7 660.2008.00496.x

Neuman, K., \& Watson, B. G. (1993) Application of paired comparison methodology in measuring Canadian's forest values. Proceedings of the Survey Research Methods Section. American Statistical Association (pp. 1091-1094).

Nkemnyi, M. F., Koedam, N., \& De Vreese, R. (2011). Livelihood and Conservation: Reconciling Communities' livelihood needs and Conservation Strategies in the Bechati forest area, Western Cameroon. Saarbrücken. Germany: LAMBERT Academic Publishing. 
Olsen, S. B. (2009). Building Capacity for the Adaptive Governance of Coastal Ecosystems Priority for the $21^{\text {st }}$ Century. Retrieved September 9, 2012, from http://www.ferrybox.eu/imperia/md/content/dahlem/wg4 paper_-_building_capacity_for_the_adaptive_governance_of_coastal_ecosystems.pdf

Overå, R. (1998). Partners and competitors. Dr.Polit Dissertation. Norway: University of Bergen.

Pomeroy, R. S., \& Carlos, M. B. (1996). A review and evaluation of community-based coastal resources management projects in the Philippines (pp. 1984-1994). ICLARM RR\# 6.

Prowse, M., \& Chimhowu, A. (2007). Making agriculture work for the poor. Natural Resource Perspectives 111. ODI, London. Retrieved July 7, 2011, from http://www.odi.org/sites/odi.org.uk/files/odi-assets/publicatio ns-opinion-files/584.pdf

Quah, E., Tan, K. C., \& Choa, E. (2003). Environmental valuation: damage schedules. Paper to be presented at the Economics and Environment Network National Workshop. May 2-3, 2003 at the Australian National University, Canberra, Australia.

Ramos, J., Santos, M., Whitemarsh, D., \& Monteiro, C. (2007). Stakeholder perceptions regarding the environmental and socio-economic impacts of the Algarve artificial reefs. Hydrobiology, 580, 181-191. http://dx.doi.org/10.1007/s10750-006-0454-z

Rodary, E. (2009). Mobilizing for nature in southern African community-based conservation policies, or the death of the local. Biodiversity Conservation, 18(10), 2585-2600. http://dx.doi.org/10.1007/s10531-009-9666-7

Savory, A. (1988). Holistic resource management. Washington, D.C.: Island Press.

Schlaepfer, R. (1997). Ecosystem-based management of natural resources: a step towards sustainable development. IUFRO Occasional Paper No. 6.

Schultz, P. W., \& Zelezny, L. (1999). Values as predictors of environmental attitudes: Evidence for consistency across cultures. Journal of Environmental Psychology, 19, 255-265. http://dx.doi.org/10.1006/jevp.199 9.0129

Schultz, P. W., Shriver, C., Tabanico, J. J., \& Khazian, A. M. (2004). Implicit connections with nature. Journal of Environmental Psychology, 24, 31-42. http://dx.doi.org/10.1016/S0272-4944(03)00022-7

Sesabo, J. K., Lang, H., \& Tol, R. S. J. (2006). Perceived Attitude and Marine Protected Areas (MPAs) establishment: Why households' characteristics matters in Coastal resources conservation initiatives in Tanzania. FNU-99.

UNDP. (2013). The Rise of the South: Human Progress in a Diverse World. Explanatory note on 2013 HDR composite indices Ghana. UNDP. Retrieved December 17, 2013, from http://hdr.undp.org/sites/default/files/Country-Profiles/GHA.pdf

United Nations Environment Programme. (2012). 21 Issues for the 21st Century: Result of the UNEP Foresight Process on Emerging Environmental Issues. United Nations Environment Programme (UNEP). Nairobi, Kenya.

World Bank. (2010). Economics of adaptation to climate change: social synthesis report. The International Bank for Reconstruction and Development.

Wright, A. S., \& Shindler, B. (2001). The role of information sources in watershed management. Fisheries, 26(11), 16-23. http://dx.doi.org/10.1577/1548-8446(2001)026<0016:TROISI $>2.0 . C O ; 2$

\section{Note}

Note 1. This encompasses the view that destructiveness is rooted in anthropocentrism, an arrogant view that we are separate from and superior to nature, which exists to serve our needs (Barnhill et al. 2006).

\section{Copyrights}

Copyright for this article is retained by the author(s), with first publication rights granted to the journal.

This is an open-access article distributed under the terms and conditions of the Creative Commons Attribution license (http://creativecommons.org/licenses/by/3.0/). 